(1) カセッデ鉛板 $0.28 \mathrm{~mm}$, (2)含鈶ゴム鉛当量 $1.5 \mathrm{~mm}$, (3)含鉛ガラス鉛当量 $2 \mathrm{~mm}$, (4)鉛板 $1.0 \mathrm{~mm}$, (5)鉛板 $2 \mathrm{~mm}$ (6)鉛板 $3 \mathrm{~mm}$, 実験方法, $9 \mathrm{~mm}$ の鉛板に $4 \mathrm{~mm}$ 径の穴を 6 ケ開けて実験材料を被写体として照射し $\mathrm{kVp}$ とT.M. を 変え黒化度と線量学測定した．電離槽型サーベメーター でX線量を測定して見たが $2 \mathrm{~mm}$ 鉛と $3 \mathrm{~mm}$ 鉛は黒化度 と線量が同じに示現している。管電圧 $100 \mathrm{kVp}$ 一定で照 射時間変化の場合は 0.1 秒にても黒化度は示現している, 私どもの胸腰椎分割像に現われたのは被写体の少ない部 分で遮蔽板のみとなった時の含鉛ゴムのためのようです。 その後 $3 \mathrm{~mm}$ の鉛板使用しているのでこのようなととは なくなった。

最近は撮影に透視に高圧を使用する傾向になった。分 割撮影はもちろんのこと照射方向の防護等は相当量の鉛 当量を必要とするわけであります。

特に透視台にての撮影の場合は距離も近くフィルムの サイズに対する絞りの大きさは術者に相当影響するもの と考えられます．X線量と黒化度，照射時間の関係必ず しも正確な数字とはいえずとも何らかの目安になれば幸 いであります。

\section{0. 自動露出遮断方式の検討}

$$
\begin{array}{lrl}
\text { 京都大学医学部 } & \text { 菅 原 } & \text { 努 } \\
\text { 三重大学医学部 } & \text { 中 村 実 } \\
\text { 東芝玉川工場 } & \\
\text { 西堀 清美 -小野 } & \text { 伸雄 - 渡辺 広行 }
\end{array}
$$

[目的]

菅原 努
中村 実

撮影の自動化の一方法として自動露出遮断方式の検討 を行なった。

[方法]

検出器にはイオン化槽を使用し, X線開閉器に機械的 接点を使用した場合，電子管制御を行なった場合のそれ ぞれについて, 管電圧特性, 被写体厚による特性, 撮影 部位に対するチェンバー形状につき検討を行なった。 [結果]

1. 管電圧特性に対して㹥変化範囲 $30 \mathrm{kV}$ 程度なら実 用上差支えない. $100 \mathrm{kV}$ 程度の変化に対しては補正を行 なった。

2. 被写体厚に対しては補正ははとんど不要であった。

\section{1. 体厚式 spot 撮影電圧選定装置の性能の検討}

国立ガンセンター放射線科

[目的]

$$
\text { 松川收作 }
$$

$\mathrm{X}$ 線撮影条件の自動化への過渡期的装置として透視撮 影時体厚式 spot 撮影電圧選定装置を使用し作業能率の
向上に寄与しているが，撮影フィルムの濃度は必ずしも 満足できるものばかりでないので試作的段階のこの装置 の諸性能の検討を行なった。

[方法] 1)

ファントームによる選定電圧を線量测定，写真濃度測 定の 2 法により検討する。2）分割撮影，斜位撮影時の 写真黒化度の過不足に対する検討をする。3）一定被検 体に対する選定電圧の許容度を調べる４4）この装置を 使用したものと，使用しないで撮影したものとの 2 者の 写真の比較を行なった。

[結果]

装置自体の性能に起因する写真濃度のバラッキがかな りある。術者の不慣れによるものも多い。しかし綜体的 に見た場合写真診断上の不都合はないものと思える。

\section{2. 透視時の撮影部位の厚さ計測についての一考案}

$$
\text { 斗南病院放射線科馬場 純市 }
$$

〔目的〕

透視時において，随時変化する撮影部位の厚さ学遠隔 操作によって，迅速に把握し適正な撮影条件を配電盤上 に表現しようとした。

[方法]

天板と蛍光板距離が撮影部位の厚さに近似的であると とを応用し，その間にスライド可能なニッケルクローム 抵抗体を取り付け，蛍光板の移動とともに変化する抵抗 值を電流計で読取ることにより撮影部位の厚さを求め, 撮影条件をきめた。

[結果及び考察]

本装置で体位, 部位によって次々に変化する厚さを迅 速に配電盤上に表現し適正な撮影条件を得ることがでる たが撮影部位の真の厚さの測定は目下検討中である。

\section{3. 試作腹部測厚計の成績}

$$
\text { 岩手県立花花厚生病院香山清之助 }
$$

嘴黒透視下での撮影条件はめくら撮影のととが多い。 透視台に簡易に取付けられる測厚計の計測值が, 制御卓 子のところで表示されるようにし，その值と撮影条件の 関係を作図して適正露出条件を得ている。その方法と結 果について報告する。

\section{4. 狭照射孔筒使用のフィルムマークの入れ方}

\section{長崎大学放射線科}

$$
\begin{aligned}
& \text { 名倉 博 - 高橋 彬・辻川太 } \\
& \text { 安岡 新 }
\end{aligned}
$$

不要X線の除去のため開孔部の狭い長尺ッーブスを使 用する撮影において，そのフィルム記号を適当な場所に 同時に記録するととはむつかしい場合もあるので，別に 